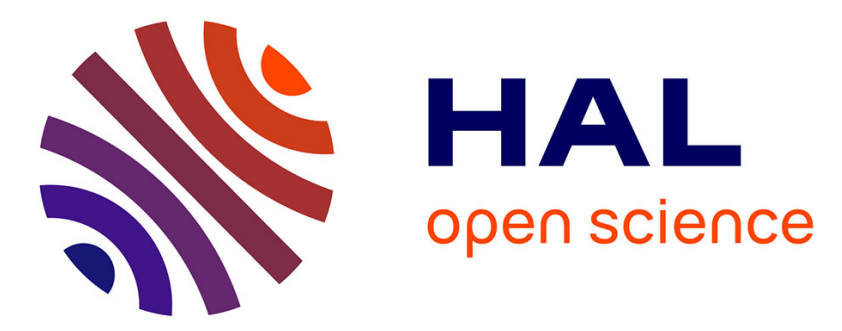

\title{
Sphingosine-1-phosphate induces proliferation of astrocytes: regulation by intracellular signalling cascades
}

A Pébay, Madeleine Toutant, J Prémont, Charles-Félix Calvo, Laurent Venance, Jocelyne Cordier, Jacques Glowinski, M. Tencé

\section{- To cite this version:}

A Pébay, Madeleine Toutant, J Prémont, Charles-Félix Calvo, Laurent Venance, et al.. Sphingosine1-phosphate induces proliferation of astrocytes: regulation by intracellular signalling cascades. European Journal of Neuroscience, 2001, 13 (12), pp.2067-76. 10.1046/j.0953-816x.2001.01585.x . hal02876775

\section{HAL Id: hal-02876775 \\ https://hal.science/hal-02876775}

Submitted on 21 Jun 2020

HAL is a multi-disciplinary open access archive for the deposit and dissemination of scientific research documents, whether they are published or not. The documents may come from teaching and research institutions in France or abroad, or from public or private research centers.
L'archive ouverte pluridisciplinaire HAL, est destinée au dépôt et à la diffusion de documents scientifiques de niveau recherche, publiés ou non, émanant des établissements d'enseignement et de recherche français ou étrangers, des laboratoires publics ou privés. 


\title{
Sphingosine-1-phosphate induces proliferation of astrocytes: regulation by intracellular signalling cascades
}

\author{
Alice Pébay, ${ }^{1}$ Madeleine Toutant, ${ }^{2}$ Joël Prémont, ${ }^{1}$ Charles-Félix Calvo, ${ }^{1}$ Laurent Venance, ${ }^{1}$ Jocelyne Cordier, ${ }^{1}$ \\ Jacques Glowinski ${ }^{1}$ and Martine Tencé ${ }^{1}$ \\ ${ }^{1}$ Chaire de Neuropharmacologie, INSERM U114, Collège de France, 11, Place Marcelin Berthelot, 75231, Paris Cedex 05, \\ France \\ ${ }^{2}$ INSERM U536, Institut du Fer à Moulin, 17 rue du Fer à Moulin, 75005, Paris, France
}

Keywords: calcium, cyclic AMP, Edg receptors, extracellular signal-regulated kinase (Erk), mouse, phospholipase C, proliferation

\begin{abstract}
Sphingosine-1-phosphate (S1P) is a potent lysophospholipid mediator mostly released by activated platelets. It is involved in several functions in peripheral tissues, but its effects in the central nervous system are poorly documented. Therefore, we have examined the effects of S1P on the proliferation of striatal astrocytes from the mouse embryo. These cells have been found to express mRNAs for the S1P receptors, Edg-1 and Edg-3. S1P stimulated thymidine incorporation and induced activation of extracellular signal-regulated kinases (Erks). Both effects were prevented by U0126, an Erk kinase inhibitor. The S1P-evoked activation of Erk1 was totally blocked in astrocytes pretreated with a combination of either phorbol ester (24 h) and LY294002, or phorbol ester $(24 \mathrm{~h})$ and pertussis toxin (PTX). Each individual treatment only partially inhibited Erk1 activation. This suggests that several separate mechanisms mediate this process, one involving protein kinase $C$ and another involving Gi/Go proteins and phosphatidylinositol 3-kinase. In contrast, the stimulatory effect of S1P on astrocyte proliferation was totally blocked by either PTX or LY294002, but not by a downregulation of protein kinase C. S1P dramatically inhibited the evoked production of cyclic AMP, a response that was impaired by PTX. Finally, S1P stimulated the production of inositol phosphates and increased intracellular calcium by mobilization from thapsigargin-sensitive stores. These latter effects were mainly insensitive to PTX. Probably, Gi/Go protein activation and phosphoinositide hydrolysis are early events that regulate the activation of Erks by S1P. Altogether, these observations show that astrocytes are targets for S1P. Their proliferation in response to S1P could have physiopathological consequences at sites of brain lesions and alterations of the blood-brain barrier.
\end{abstract}

\section{Introduction}

Sphingosine-1-phosphate (S1P), one of the sphingolipid metabolites, has recently emerged as a potent and pleiotropic bioactive lysophospholipid regulating a number of cellular events, such as cell proliferation, migration, cytoskeletal remodelling and apoptosis. S1P is most probably involved in wound healing, inflammation, vasoconstriction, tumour invasion and angiogenesis (see reviews in Goetzl \& An, 1998; Moolenaar, 1999; Pyne \& Pyne, 2000; Spiegel \& Milstein, 2000). Like lysophosphatidic acid (LPA) or plateletactivating factor, two other biologically active small phospholipids, S1P mainly originates from activated platelets and is transported in the blood bound to serum albumin (Yatomi et al., 1997a; Edsall \& Spiegel, 1999).

S1P can act on its target cells through the activation of $\mathrm{G}$ protein-coupled receptors. As reported recently, these receptors are encoded by genes belonging to the $E d g$ (endothelial differentiation gene) family. This family, also named lysophospholipid (LP) receptor genes (Chun, 1999), consists of at least eight members. S1P is the preferential ligand of Edg-1 (also referred to as $\left.\mathrm{LP}_{\mathrm{B} 1}\right), \mathrm{Edg}-3\left(\mathrm{LP}_{\mathrm{B} 3}\right), \mathrm{Edg}-5\left(\mathrm{AGR} 16 / \mathrm{H} 218\right.$ or $\left.\mathrm{LP}_{\mathrm{B} 2}\right)$, Edg-6

Correspondence: Dr Martine Tencé, as above.

E-mail: martine.tence@college-de-france.fr

Received 22 November 2000, revised 26 March 2001, accepted 4 April 2001 and Edg-8 (Nrg-1) receptors (Lee et al., 1998; Okamoto et al., 1999; Van Brocklyn et al., 1999; Zhang et al., 1999; Im et al., 2000; Van Brocklyn et al., 2000; Yamazaki et al., 2000; Malek et al., 2001). Transfection experiments have been performed to determine the responses specifically mediated by each of these receptor subtypes (Lee et al., 1998; Okamoto et al., 1998, 1999; Zondag et al., 1998; An et al., 1999; Kon et al., 1999; Im et al., 2000; Malek et al., 2001). Using $\left[{ }^{35} \mathrm{~S}\right] \mathrm{GTP} \gamma \mathrm{S}$ autoradiography, Waeber \& Chiu (1999) have provided evidence for a widespread distribution of S1P receptors in the brain, the striatum being one of the labelled structures.

In pathological situations resulting from brain trauma and haemorrhage, substances such as S1P, which are released from platelets during blood clotting, may contact nervous cells. As suggested recently, these cells are indeed responsive to S1P. This lysosphingolipid triggers profound morphological changes, such as neurite retraction, soma rounding or cell aggregation in neuroblastoma and neocortical neuroblast cell lines (Postma et al., 1996; Ishii \& Chun, 1999). S1P can either promote apoptosis in neurons (Moore et al., 1999) or protect against apoptosis induced by serum withdrawal in PC12 cells (Edsall et al., 1997). Finally, S1P has also been shown to act on oligodendrocytes, C6 glioma cells and cerebral astroglial cells (Tas \& Koschel, 1998; Hida et al., 1999; Sato et al., 1999a, b). 
TABLE 1. Primer pairs used in PCR reactions

\begin{tabular}{lll}
\hline $\begin{array}{l}\text { Edg } \\
\text { receptor }\end{array}$ & Primer sequence & $\begin{array}{l}\text { PCR product } \\
\text { size (bp) }\end{array}$ \\
\hline $\begin{array}{l}\text { Edg-1 } \\
\text { (mouse) }\end{array}$ & $\begin{array}{l}5^{\prime} \text {-GAACTTTGCGAGTAGCTGG-3' (S) } \\
5^{\prime} \text {-TGCGGAGAGCTTTAACCTCC-3' (AS) }\end{array}$ & 320 \\
$\begin{array}{l}\text { Edg-3 } \\
\text { (mouse) }\end{array}$ & $\begin{array}{l}5^{\prime} \text {-ACCACTCTCCCAATTGTTCC (S) } \\
5^{\prime} \text {-CGTAATCGTAATGTTCCCGG-3' (AS) }\end{array}$ & 160 \\
$\begin{array}{l}\text { Edg-5 } \\
\text { (mouse) }\end{array}$ & $\begin{array}{l}5^{\prime} \text {-TTAACTCCCGTGCAGTGGTTTGC-3' (S) } \\
\text { 5'-ACGATGGTGACCGTCTTGAGCA-3' (AS) }\end{array}$ & 416 \\
\hline
\end{tabular}

AS, antisense; S, sense.

Astrocyte proliferation is an essential event following brain lesions. The present study, carried out on striatal astrocytes from the mouse embryo, was thus undertaken to determine whether S1P is involved in this process. Attempts were also made to look for the presence of S1P receptors on these cells and to identify the intracellular signalling cascades which could be responsible for the proliferative effect of S1P. The following data have been reported previously in abstract form (Tencé et al., 1999).

\section{Materials and methods}

\section{Materials}

S1P was obtained from Biomol (Plymouth Meeting, PA, USA) and dissolved in methanol. Extemporaneal dilutions of S1P were made in water containing $0.1 \%$ fatty acid-free bovine serum albumin (BSA) (Sigma, St Louis, MO, USA). Isobutylmethylxanthine, isoproterenol, poly L-ornithine, Indo-1 acetoxymethyl ester (Indo-1 AM) and cytosine arabinoside were from Sigma. Pertussis toxin (PTX) was from List Biological Laboratories (Campbell, CA, USA). Phorbol 12myristate 13-acetate (PMA), thapsigargin, LY294002 and forskolin were from Calbiochem (San Diego, CA, USA). U0126 was obtained from Promega (Charbonnières, France). Dulbecco's modified Eagle's medium (DMEM), minimum essential medium (MEM) and F12 (Ham) were from Life Technologies (Grand Island, NY, USA). Myo$\left[{ }^{3} \mathrm{H}\right]$ inositol $17 \mathrm{Ci} / \mathrm{mmol}$ and $\left[{ }^{3} \mathrm{H}\right]$ adenine $(24 \mathrm{Ci} / \mathrm{mmol})$ were from Amersham (Amersham, UK). [Methyl- $\left.{ }^{3} \mathrm{H}\right]$-thymidine $(2 \mathrm{Ci} / \mathrm{mmol})$ was from NEN Life Science Products (Boston, MA, USA).

\section{Cell culture}

Swiss mice (Iffa Credo, Lyon, France) were killed by prolonged exposure to a high concentration of carbon dioxide, and embryos were dissected from the uterus and recovered in phosphate-buffered saline supplemented with $33 \mathrm{~mm}$ glucose. Primary cultures of striatal astrocytes were prepared, as described previously (El-Etr et al., 1989). Briefly, the striata, removed from 16-day-old embryos, were mechanically dissociated and cells were plated in either 24-well (seeded at $3 \times 10^{5}$ cells per well), 12 -well $\left(7 \times 10^{5}\right.$ cells per well) or six-well $\left(1 \times 10^{6}\right.$ cells per well $)$ Nunc culture plates, or glass slides $\left(5 \times 10^{6}\right.$ cells per plate) previously coated with $1.5 \mu \mathrm{g} / \mathrm{mL}$ poly L-ornithine. The culture medium consisted of a mixture of MEM and F12 nutrient $(1: 1)$ supplemented with $33 \mathrm{~mm}$ glucose, $2 \mathrm{~mm}$ glutamine, $14 \mathrm{~mm}$ sodium bicarbonate, $5 \mathrm{~mm} \mathrm{~N}$-2[hydroxyethyl]piperazine- $N^{\prime}$-[2-ethanesulphonic acid] (HEPES) buffer (pH 7.4) and $10 \%$ Nu-serum (Collaborative Biomed. Products, Bedford, MA, USA). Cells were cultured at $37{ }^{\circ} \mathrm{C}$ in a humidified atmosphere of $95 \%$ air and $5 \% \mathrm{CO}_{2}$. The culture medium was first changed on day 4 and thereafter twice a week. On day 8 , cytosine arabinoside $(2 \mu \mathrm{M})$ was added for 3 days to avoid proliferation of microglial cells (except for thymidine incorporation experiments). In these conditions, following 21-26 days in culture, more than $95 \%$ of the cells were stained by the indirect immunofluorescence technique using a monoclonal mouse antiglial fibrillary acidic protein (ICN Biomedicals, Costa Mesa, CA, USA). Unless otherwise stated, experiments were performed on cultures grown to confluency (2126 days) and made quiescent by serum deprivation for 18-20 h. NIH $3 \mathrm{~T} 3$ cells (Aaronson; NCI, NIH, Bethesda, MD, USA) were grown in DMEM containing $10 \%$ fetal calf serum.

\section{Reverse transcriptase-polymerase chain reaction (RT-PCR) experiments}

Total RNA was extracted from astrocyte cultures using the guanidine isothiocyanate method (Chomszynski \& Sacchi, 1987). Reverse transcription was performed with $10 \mu \mathrm{g}$ of total RNA and primed with $1 \mu \mathrm{g}$ of oligo $\mathrm{d}(\mathrm{T})_{15}$ (Boehringer Mannheim, Mannheim, Germany) in the presence of $8 \mathrm{U}$ RNAsin (Promega, Madison, WI, USA). This mixture was first heated to $70{ }^{\circ} \mathrm{C}$ for $5 \mathrm{~min}$ and the reaction was then carried out in a mixture (final volume, $50 \mu \mathrm{L}$ ) including $400 \mathrm{U}$ of MMLV reverse transcriptase (Life Technologies) and $4 \mathrm{mM}$ dithiothreitol in a buffer containing $50 \mathrm{~mm}$ Tris- $\mathrm{HCl}$ (pH 8.3), $7.5 \mathrm{mM} \mathrm{KCl}, 3 \mathrm{~mm} \mathrm{MgCl}_{2}, 8 \mathrm{U}$ RNAsin and $2 \mathrm{~mm}$ of each dATP, dGTP, dCTP and dTTP (dNTP mix, Life Technologies). This mixture was incubated at $37{ }^{\circ} \mathrm{C}$ for $45 \mathrm{~min}$ and the reaction was terminated by heating at $100{ }^{\circ} \mathrm{C}$ for $5 \mathrm{~min}$. After cooling on ice, reverse transcriptase was added again and the mixture was incubated for an additional $30 \mathrm{~min}$ at $37{ }^{\circ} \mathrm{C}$ before heating at $100{ }^{\circ} \mathrm{C}$. cDNA samples were amplified by PCR with sense and antisense primers (synthesis performed by Genset SA Europe, Paris, France) designed for specific detection of gene sequences for mouse Edg-1, Edg-3 and Edg-5 receptors. Primers for Edg-1 and Edg-3 receptor genes (Table 1) were selected through computer analysis using Gene Works software from the sequences published by Liu \& Hla (1997) (accession number NM010101; K. Ohta, A. Wada \& Y. Igarashi, unpublished results), respectively. For the Edg-5 receptor gene we used the primer pair previously designed by Zhang et al. (1999) (Table 1). PCR experiments were performed in a mixture $(50 \mu \mathrm{L})$ containing 1.5 U of Taq DNA polymerase (Life Technologies) and $1 \mu \mathrm{M}$ of each primer in a buffer containing $20 \mathrm{mM}$ Tris- $\mathrm{HCl}(\mathrm{pH} \mathrm{8.4})$, $\mathrm{MgCl}_{2}$ (1.5 mM for Edg-1 and Edg-3 and $2.5 \mathrm{~mm}$ for Edg-5), $50 \mathrm{~mm}$ $\mathrm{KCl}$, and $0.2 \mathrm{mM}$ of each dATP, dGTP, dCTP and dTTP. The absence of contaminating genomic DNA was checked by control reactions with RNA not treated with reverse transcriptase. PCR experiments were run in a Perkin Elmer Cetus DNA Thermal Cycler programmed for the following steps: initial denaturation at $94{ }^{\circ} \mathrm{C}$ for $5 \mathrm{~min}, 40$ cycles of denaturation at $94{ }^{\circ} \mathrm{C}$ for $1 \mathrm{~min}$, annealing at $55^{\circ} \mathrm{C}$ for $1 \mathrm{~min}$

and a primer extension step at $72{ }^{\circ} \mathrm{C}$ for $2 \mathrm{~min}$. Specific amplified DNA fragments were purified by electrophoresis on $1.5 \%(\mathrm{w} / \mathrm{v})$ agarose gel, stained with ethidium bromide and photographed. Amplicons were purified and sequenced by Genome Express SA (Montreuil-sous-bois, France).

\section{$\left[{ }^{3} \mathrm{H}\right]$ thymidine incorporation}

Astrocytes grown to subconfluency in 12-well plates were washed with serum-free medium and then incubated in fresh serum-free medium for $24 \mathrm{~h}$ before incubation with S1P (or vehicle) for a further 24-h period. When stated, cells were pretreated with either PTX $(100 \mathrm{ng} / \mathrm{mL}, 18 \mathrm{~h})$ or PMA $(1 \mu \mathrm{M}, 24 \mathrm{~h})$ before the application of S1P. [Methyl- ${ }^{3} \mathrm{H}$ ]thymidine $(1 \mu \mathrm{Ci} / \mathrm{mL})$ was added during the last 18 $\mathrm{h}$ of incubation. Radioactivity incorporated into the trichloroacetic acid $(10 \%)$-precipitable material was measured after solubilization 

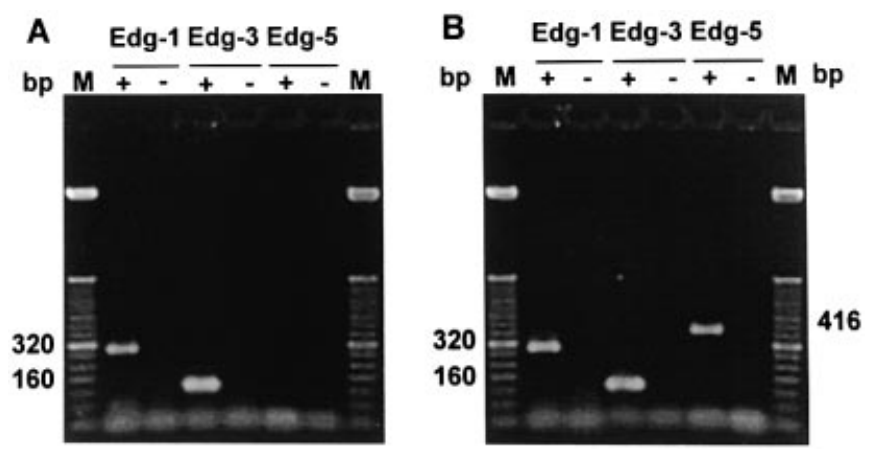

FIG. 1. Detection of Edg receptor mRNAs by RT-PCR analysis. RT-PCR experiments were performed using total RNA isolated from either mouse striatal astrocytes (A) or NIH $3 \mathrm{~T} 3$ fibroblasts (B), and specific primers for mouse Edg-1, Edg-3 and Edg-5 genes. In each case, experiments were conducted in either the presence $(+)$ or absence $(-)$ of reverse transcriptase. RT-PCR products were separated by electrophoresis on $1.5 \%$ agarose gel and revealed by ethidium bromide fluorescence, and their molecular size (in bp) was calculated using $50 \mathrm{bp}$ DNA ladder markers (M). These data are representative of results obtained with four different cultures of astrocytes. Three independent PCR experiments were performed on each RNA preparation.

with $0.1 \%$ (w/v) sodium dodecyl sulphate (SDS) in $0.1 \mathrm{M} \mathrm{NaOH}$, followed by $0.1 \%$ SDS in $0.1 \mathrm{M} \mathrm{HCl}$.

\section{Extracellular signal-regulated kinase (Erk) activation}

Astrocytes grown in six-well plates were pretreated or not with PTX $(1 \mu \mathrm{g} / \mathrm{mL}, 18 \mathrm{~h})$ and/or PMA $(1 \mu \mathrm{M}, 24 \mathrm{~h})$, and then incubated (in $2 \mathrm{~mL}$ ) with S1P (or vehicle). Incubations were terminated by removal of the supernatants and addition of $160 \mu \mathrm{L}$ of a hot solution of $1 \%$ SDS and $1 \mathrm{~mm}$ sodium orthovanadate. Samples were boiled for $5 \mathrm{~min}$ and protein lysates ( $100 \mu \mathrm{g}$ per lane) were resolved by SDSpolyacrylamide gel electrophoresis (10\% polyacrylamide, w/v). Proteins were transferred onto nitrocellulose membranes (HybondECL, Amersham) and immunoblotting was carried out with polyclonal anti-active mitogen-activated protein (MAP) kinase antibodies raised against a dually phosphorylated MAP kinase peptide (dilution, 10 000) (Promega). Peroxidase-coupled secondary antibodies (dilution, 4000) (Amersham) were detected by exposure of autoradiographic films in the presence of a chemiluminescent reagent (Renaissance, Dupont-NEN, Boston, MA, USA). Stripping of antibodies was achieved by incubating the membrane during $1 \mathrm{~h}$ in a buffer containing $100 \mathrm{~mm}$ glycine, $\mathrm{pH} 2.5$, and $100 \mathrm{~mm} \beta$-mercaptoethanol. The membrane was further incubated with monoclonal mouse anti-MAP kinase (dilution, 5000; Zymed, San Francisco, CA, USA) and then with peroxidase-coupled antimouse IgG secondary antibodies (dilution, 4000; Amersham). Densitometric analysis was performed after scanning autoradiographic films using a Kodak Digital Science Image Station 440 system (Eastman Kodak Company, Rochester, NY, USA).

\section{$\left[{ }^{3} \mathrm{H}\right]$-Inositol phosphate formation}

Astrocytes grown in 24-well plates were incubated overnight in the presence of $1 \mu \mathrm{Ci} / \mathrm{mL}$ of myo- $\left[{ }^{3} \mathrm{H}\right]$ inositol added to the culture medium in either the absence or presence of PTX $(1 \mu \mathrm{g} / \mathrm{mL})$. Cells were washed three times at $37{ }^{\circ} \mathrm{C}$ with Krebs phosphate buffer pH 7.4 (in mM: $\mathrm{NaH}_{2} \mathrm{PO}_{4} 15.6 ; \mathrm{NaCl} 120 ; \mathrm{KCl} 4.8 ; \mathrm{MgSO}_{4} 1.2$; $\mathrm{CaCl}_{2} 1.2$; glucose 33 ) containing $0.1 \%$ fatty acid-free BSA. They were then preincubated for $10 \mathrm{~min}$ with the same buffer supplemented with lithium chloride (10 mM). Incubation (in $0.5 \mathrm{~mL}$ ) with
S1P (or vehicle) was carried out at $37{ }^{\circ} \mathrm{C}$ in the same medium. The reaction was stopped by adding successively $0.2 \mathrm{~mL}$ of $0.1 \%(\mathrm{v} / \mathrm{v})$ Triton $\mathrm{X} 100$ in $0.1 \mathrm{M} \mathrm{NaOH}, 0.5 \mathrm{~mL}$ water and $0.2 \mathrm{~mL}$ of Triton $\mathrm{X} 100$ in $0.1 \mathrm{M} \mathrm{HCl}$. Free $\left[{ }^{3} \mathrm{H}\right]$ inositol and total $\left[{ }^{3} \mathrm{H}\right]$-labelled inositol phosphates were isolated as described previously (El-Etr et al., 1989).

\section{Calcium assay}

Variations in intracellular calcium concentration $\left(\left[\mathrm{Ca}^{2+}\right] \mathrm{i}\right)$ were measured under dual-emission video-fluoromicroscopy using the cell-permeant fluorescent dye Indo-1 AM, as described previously (Delumeau et al., 1991). Striatal astrocytes grown on glass slides were pretreated or not with PTX $(1 \mu \mathrm{g} / \mathrm{mL}, 18 \mathrm{~h})$ and then placed in a perfusion chamber. After washing with buffer, $\mathrm{pH} 7.4$ (in $\mathrm{mM}$ :

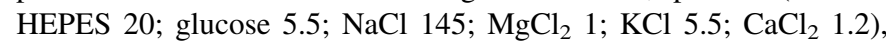
cells were loaded for $45 \mathrm{~min}$ at $37^{\circ} \mathrm{C}$ with Indo-1 AM $(12 \mu \mathrm{M})$. They were then washed several times with the buffer and perfusion chamber was placed in an inverted microscope equipped with a calcium imaging set up (Hamamatsu, Massy, France). Cells were exposed to various substances using a multichannel device, allowing complete change of the medium in less than $200 \mathrm{~ms}$. They were excited with a $75-\mathrm{W}$ xenon light, filtered at $340 \mathrm{~nm}$ with a 10-nmwide interferential filter. Excitation and emission were separated by a 380-nm dichroic long-pass filter and the emission spectra were then divided in two halves by a dichroic long-pass filter (Nikon, France). Two discriminant bands were selected from the two halves at 400410 and $470-480 \mathrm{~nm}$, and both fluorescent images were digitized. Fluorescence was measured simultaneously at 3-s intervals in 14 individual astrocytes. Variations of $\left[\mathrm{Ca}^{2+}\right] \mathrm{i}$ were expressed as the fluorescence ratio measured at 405 and $480 \mathrm{~nm}$.

\section{$\left[{ }^{3} \mathrm{H}\right]$ cyclic AMP formation}

Astrocytes grown in 24-well plates were pretreated or not for $18 \mathrm{~h}$ with PTX $(1 \mu \mathrm{g} / \mathrm{mL})$ and then incubated for $2 \mathrm{~h}$ with $1 \mu \mathrm{Ci} / \mathrm{mL}$ of $\left[{ }^{3} \mathrm{H}\right]$ adenine added to the culture medium. After washing with Krebs phosphate buffer containing BSA (discussed earlier), cells were exposed to $\mathrm{S} 1 \mathrm{P}$ (or vehicle) at $37{ }^{\circ} \mathrm{C}$ in the same medium (in $0.5 \mathrm{~mL}$ ) supplemented with $1 \mathrm{~mm}$ isobutylmethylxantine. Incubations were terminated by adding $0.5 \mathrm{~mL}$ of trichloroacetic acid $(10 \%, \mathrm{w} / \mathrm{v})$. $\left[{ }^{3} \mathrm{H}\right]$ cyclic AMP $\left(\left[{ }^{3} \mathrm{H}\right] \mathrm{cAMP}\right)$ was separated from other radioactive compounds, as described by Sagan et al. (1996).

\section{Presentation of data}

All assays were performed in triplicate or quadruplicate. Each set of experiments was performed at least three times ( $n$ refers to the number of independent experiments performed on different cell cultures). Data are expressed as mean \pm SEM. Significance of the differences between the means was evaluated using ANOVA followed by Student-Newman-Keuls test.

\section{Results}

\section{Detection of Edg receptor mRNAs}

Using primers designed from the mouse gene sequences, RT-PCR experiments were performed to investigate whether mRNAs for Edg1, Edg-3 and Edg-5 receptors were expressed in primary cultures of mouse striatal astrocytes. The expression of S1P receptor mRNAs was also determined in NIH $3 \mathrm{~T} 3$ fibroblasts to validate our experiments as specific transcripts for Edg-1, Edg-3 and Edg-5 receptor genes have been demonstrated in these cells (Sato et al., 1999a). As expected, NIH 3T3 cells contained mRNA for Edg-1, Edg-3 and Edg-5 receptors, as indicated by the presence of bands of 
320, 160 and $416 \mathrm{bp}$, respectively (Fig. 1B). Messenger RNAs for Edg-1 and Edg-3, but not Edg-5, were found in striatal astrocytes (Fig. 1A). Analysis of the purified PCR products revealed that their nucleotide sequences were identical to corresponding regions in the mouse receptor genes.
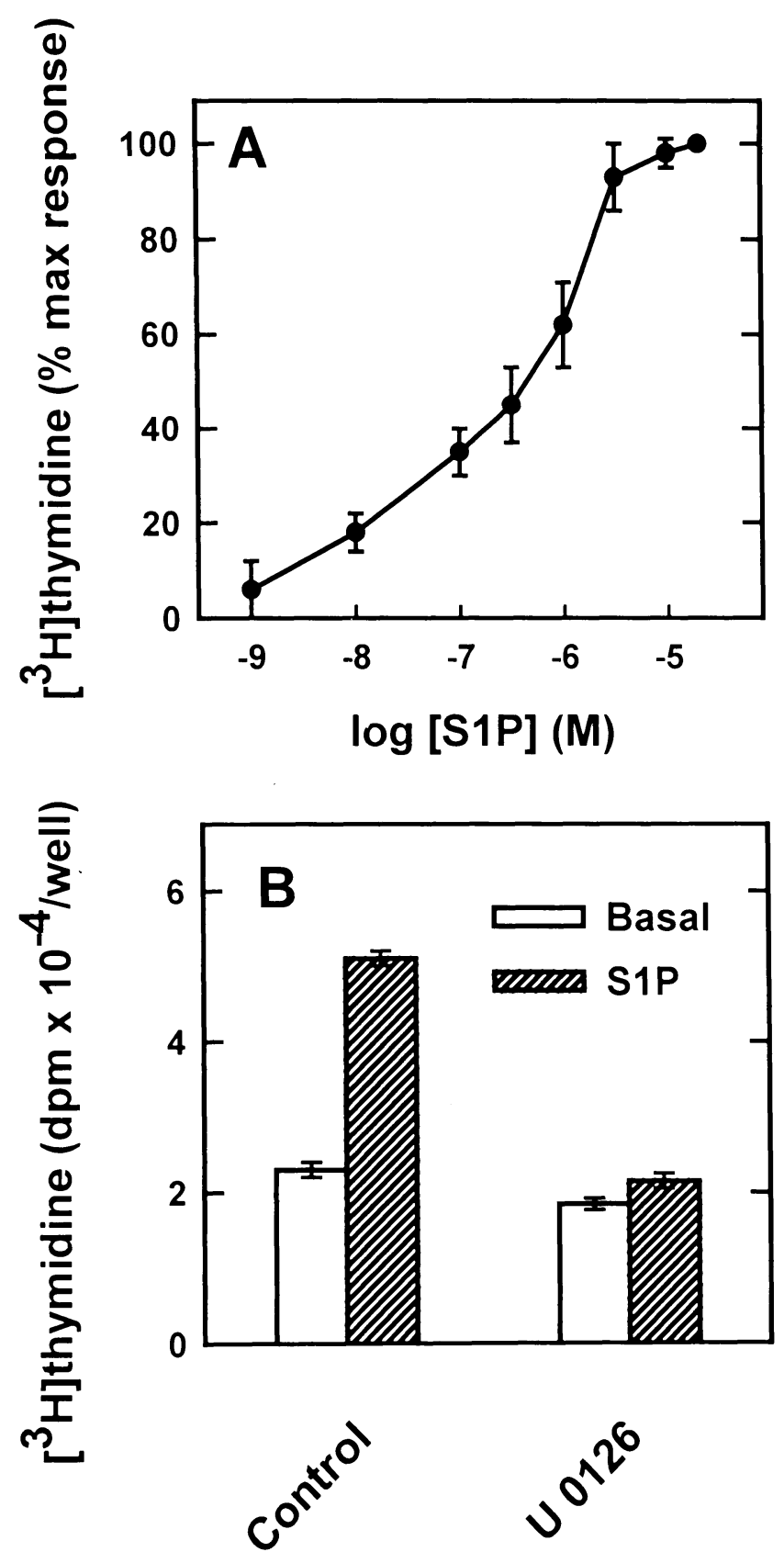

FIG. 2. S1P-induced DNA synthesis. (A) Cells were treated with increasing concentrations of S1P for $24 \mathrm{~h}$. Data are expressed as a percentage of the maximal stimulation induced by $10 \mu \mathrm{M} \mathrm{S1P}$ and are the means \pm SEM of results from at least four experiments, each run in quadruplicate. (B) Cells were pretreated or not (control) with U0126 (30 $\mu \mathrm{M}, 60 \mathrm{~min})$ before being incubated for $24 \mathrm{~h}$ with $10 \mu \mathrm{M} \mathrm{S1P}$. Data are the mean \pm SEM of four determinations and are representative of results obtained in at least four independent experiments.

\section{S1P stimulates cell proliferation: requirement for Erk activation}

The effect of S1P on the proliferation of striatal astrocytes was assessed by measuring [methyl- ${ }^{3} \mathrm{H}$ ] thymidine incorporation as an index of DNA synthesis. Prolonged application (24 h) of increasing S1P concentrations on quiescent cells resulted in a concentrationdependent increase in thymidine incorporation when compared with control cells (incubated with the vehicle) $\left(\mathrm{EC}_{50}=0.33 \pm 0.07 \mu \mathrm{M}\right.$, $n=4$ ) (Fig. 2A). At $10 \mu \mathrm{M}, \mathrm{S} 1 \mathrm{P}$ caused an increase of $82 \pm 7 \%$ over control cells $(n=22)$.

In several cell types, activation of Erk is necessary for the effects of mitogens. As shown in Fig. 2B, this is also the case in astrocytes treated with $\mathrm{S} 1 \mathrm{P}$, as the $\mathrm{S} 1 \mathrm{P}(10 \mu \mathrm{M})$-induced stimulation of DNA synthesis was prevented totally in cells pretreated with the Erk kinase (MEK) inhibitor, U0126 (30 $\mu \mathrm{M}, 60 \mathrm{~min}$ ). This observation led us to investigate the effect of S1P on Erk activation. Anti-phospho-MAP kinase antibodies were used to detect phosphorylated Erk1 and Erk2, the activated forms of these proteins. While no (or only a weak) immunoreactive band corresponding to Erk2 (42 kDa) was detected in lysates from untreated astrocytes, two strong immunoreactive bands corresponding to Erk1 (44 kDa) and Erk2 were observed when astrocytes were incubated for 5 min with S1P (10 $\mu \mathrm{M})$ (Fig. 3A). The activation of Erk1 and Erk2 lasted for at least $60 \mathrm{~min}$ (Fig. 3A). Erk1 and Erk2 were no longer activated after a 5-h incubation of astrocytes with S1P (Fig. 3A). Finally, the S1P-induced activation of Erk1 and Erk2 were totally inhibited by U0126 (Fig. 3B).

\section{S1P stimulates phosphoinositide hydrolysis and inhibits $C A M P$ production}

It has been reported recently (Okamoto et al., 1998, 1999; Zondag et al., 1998; An et al., 1999; Kon et al., 1999) that S1P modulates the activity of phospholipase $\mathrm{C}$ and adenylate cyclase in cells overexpressing Edg-1 or Edg-3 receptors. These initial responses could be responsible for S1P-induced activation of Erks in striatal astrocytes. Therefore, the effects of S1P on the hydrolysis of phosphoinositides (measured by production of inositol phosphates and changes in $\left.\left[\mathrm{Ca}^{2+}\right] \mathrm{i}\right)$ and the production of cAMP were also examined.

As shown in Fig. 4A, S1P $(10 \mu \mathrm{M})$ enhanced in a time-dependent manner the accumulation of $\left[{ }^{3} \mathrm{H}\right]$-inositol phosphates in striatal astrocytes prelabelled with myo- $\left[{ }^{3} \mathrm{H}\right]$ inositol. This response lasted for at least $60 \mathrm{~min}$ and $\left[{ }^{3} \mathrm{H}\right]$-inositol phosphate production reached at least threefold the basal value $(233 \pm 23 \%$ above basal value, $n=28$ ) after $15 \mathrm{~min}$ of incubation. This S1P response was concentration-dependent, the half-maximal concentration being $0.15 \pm 0.02 \mu \mathrm{M}(n=4)$ (Fig. 4B). The S1P $(10 \mu \mathrm{M})$-evoked production of $\left[{ }^{3} \mathrm{H}\right]$-inositol phosphates was modestly reduced in the absence of external calcium, but strongly impaired when astrocytes were treated for 10 min with PMA $(1 \mu \mathrm{M})$ (to activate protein kinase C) before S1P application (Table 2). The S1P-evoked response was also weakly reduced when cells were pretreated with PTX (Table 2) indicating that phosphoinositide hydrolysis occurs through a mechanism essentially independent of Gi/Go proteins.

As shown in Fig. 5, S1P $(10 \mu \mathrm{M})$ induced a rapid and marked increase in $\left[\mathrm{Ca}^{2+}\right] \mathrm{i}$ in striatal astrocytes. In all tested cells, the increase in $\left[\mathrm{Ca}^{2+}\right] \mathrm{i}$ occurred with a lag period of 5-10 $\mathrm{s}$ and was biphasic with a transient elevation followed by a sustained increase (Fig. 5A). The increase in $\left[\mathrm{Ca}^{2+}\right] \mathrm{i}$ was triggered with a S1P concentration as low as $0.01 \mu \mathrm{M}$ (not shown). Several successive applications of S1P led to an attenuation of this calcium response (Fig. 5A). The initial phase of the response persisted in the absence of external calcium and in the presence of $2 \mathrm{~mm}$ ethylene glycol-bis( $\beta$ aminoethyl ether)- $N, N, N^{\prime}, N^{\prime}$-tetraacetic acid ethylene glycol (EGTA) 
A

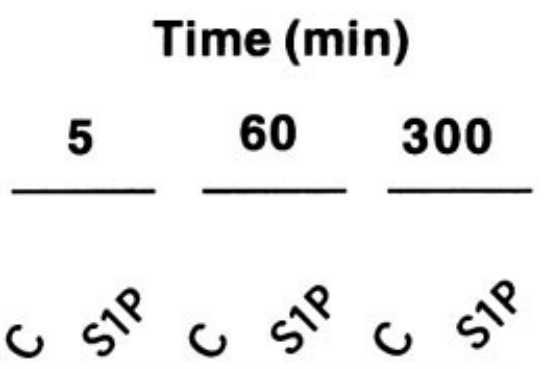

P-Erk1 P-Erk2

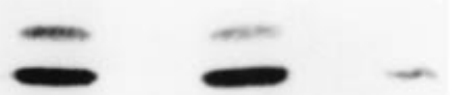

P-Erk immunoblot

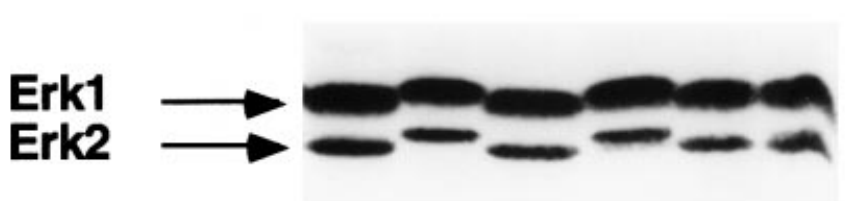

Erk immunoblot

B

\section{U0126}
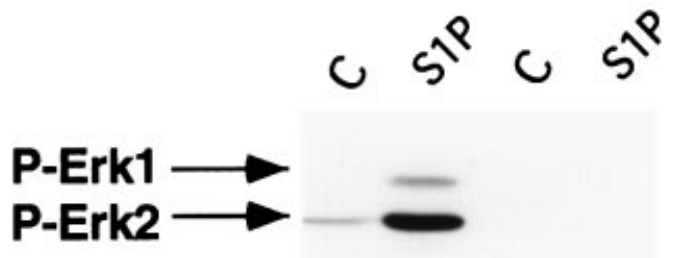

P-Erk immunoblot

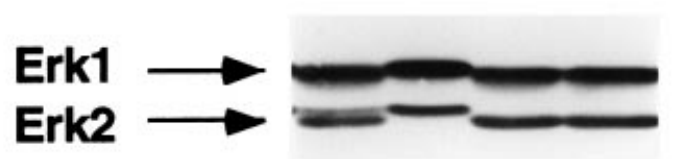

Erk immunoblot
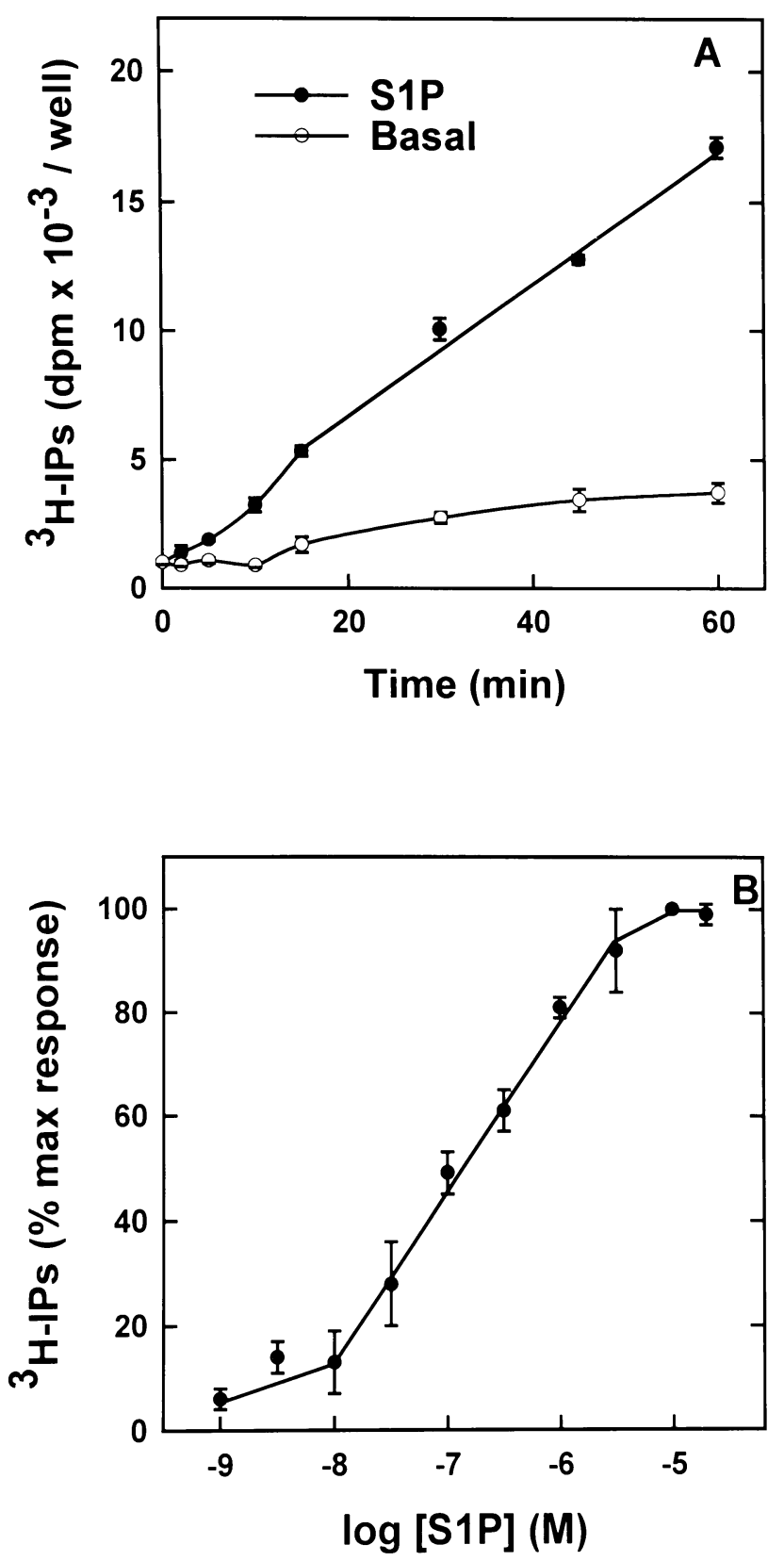

FIG. 4. S1P-induced production of $\left[{ }^{3} \mathrm{H}\right]$-inositol phosphates $\left({ }^{3} \mathrm{H}-\mathrm{IPs}\right)$. (A) Myo- $\left[{ }^{3} \mathrm{H}\right]$ inositol-labelled cells were incubated for various times in the absence (basal) or presence of $10 \mu \mathrm{M} \mathrm{S1P}$. Data are the means \pm SEM of three determinations and are representative of results obtained in three independent experiments. (B) Cells were incubated in the presence of increasing concentrations of S1P. Data, expressed as a percentage of the maximal stimulation induced by $10 \mu \mathrm{M} \mathrm{S1P}$, are the means \pm SEM of results from four experiments, each run in triplicate.

FIG. 3. S1P-induced activation of Erks. (A) Cells were incubated for various times in the absence (C, control) or presence of $10 \mu \mathrm{M} \mathrm{S1P.} \mathrm{(B)} \mathrm{Cells} \mathrm{were}$ pretreated or not with $\mathrm{U} 0126(30 \mu \mathrm{M}, 60 \mathrm{~min})$ and then incubated for $5 \mathrm{~min}$ in the absence (C) or presence of $10 \mu \mathrm{M} \mathrm{S1P.} \mathrm{Phosphorylation} \mathrm{of} \mathrm{Erk1} \mathrm{and}$ Erk2 (P-Erk1 and P-Erk2) was assessed by immunoblotting with a polyclonal antibody specific for the dually phosphorylated forms of Erk1 and Erk2. After a stripping procedure, the same membranes were reprobed with a monoclonal anti-MAP kinase to ensure equal loading of proteins. It can be noted that long-term incubation with S1P (A) did not affect the amounts of Erk1 and Erk2 when compared with untreated cells. Data are representative of results from two independent experiments. 
(Fig. 5B). Astrocytes no longer responded to S1P application when they were preincubated with thapsigargin $(10 \mu \mathrm{M}, 3 \mathrm{~min})$, an inhibitor of the reticulum calcium-ATPase pump (Fig. 5C). Finally, this S1P-evoked increase in $\left[\mathrm{Ca}^{2+}\right]$ i was not affected when cells were pretreated with PTX (not shown). Thus, the initial phase of the S1P response results from a release of calcium from intracellular stores through a mechanism essentially independent of Gi/Go proteins.

S1P $(10 \mu \mathrm{M})$ was ineffective in stimulating the production of $\left[{ }^{3} \mathrm{H}\right] \mathrm{cAMP}$ in striatal astrocytes prelabelled with $\left[{ }^{3} \mathrm{H}\right]$ adenine (not shown). In contrast, S1P dramatically inhibited the forskolin (10 $\mu \mathrm{M})$ evoked accumulation of $\left[{ }^{3} \mathrm{H}\right] \mathrm{cAMP}$ (Fig. 6A). The maximal inhibitory effect of S1P was observed as early as $3-5 \min (-78 \pm 2 \%$ of the forskolin-evoked response, $n=16$ ) (Fig. 6A). This S1P-evoked response was concentration-dependent with an $\mathrm{IC}_{50}$ of $0.04 \pm 0.01 \mu \mathrm{M}(n=4)$ (Fig. 6B). The inhibitory effect of S1P $(10 \mu \mathrm{M})$ was strongly impaired in astrocytes pretreated with PTX (the forskolin-evoked accumulation of cAMP being only reduced by

TABLE 2. Effect of various treatments on the S1P-evoked production of $\left[{ }^{3} \mathrm{H}\right]$-inositol phosphates

\begin{tabular}{ll}
\hline Condition & $\begin{array}{l}{\left[{ }^{3} \mathrm{H}\right]-\text { inositol }} \\
\text { phosphates }(\%)^{\dagger}\end{array}$ \\
\hline S1P (control condition) & 100 \\
S1P in a calcium-free buffer & $81 \pm 5^{*}$ \\
S1P in cells preincubated with PMA & $27 \pm 5^{* *}$ \\
S1P in cells treated with PTX & $76 \pm 8^{*}$ \\
\hline
\end{tabular}

${ }^{\dagger}$ Percentage of maximum response. Myo- $\left[{ }^{3} \mathrm{H}\right]$ inositol-prelabelled striatal astrocytes were pretreated or not (control condition) with PTX $(1 \mu \mathrm{g} / \mathrm{mL}$, $18 \mathrm{~h})$ or PMA $(1 \mu \mathrm{M}, 10 \mathrm{~min})$ before being incubated for $15 \mathrm{~min}$ with $10 \mu \mathrm{M}$ S1P in a calcium-containing buffer or in a buffer depleted in calcium and supplemented with EGTA ( $2 \mathrm{mM})$. In each experimental condition, the production of $\left[{ }^{3} \mathrm{H}\right]$-inositol phosphates evoked by S1P was compared with the corresponding basal value obtained with the vehicle alone. Results, expressed as a percentage of the S1P-evoked response obtained in control condition, are the means \pm SEM of data obtained in at least four experiments, each performed in triplicate. $* P<0.05 ; * * P<0.001$ compared with the value obtained in control conditions.
$7 \pm 2 \%, n=4)$. Isoproterenol $(10 \mu \mathrm{M})$ also stimulated the accumulation of $\left[{ }^{3} \mathrm{H}\right] \mathrm{cAMP}(10-25$-fold the basal cAMP value, $n=3)$ and this response was strongly inhibited by S1P $(-73 \pm 7 \%$ of the evoked response, $n=3$ ) (not shown). These data indicate that S1P inhibits the evoked production of cAMP through a mechanism involving $\mathrm{Gi} / \mathrm{Go}$ proteins.

Roles of protein kinase $C$, phosphatidylinositol 3-kinase (PI 3-kinase) and Gi/Go proteins in the S1P-evoked activation of Erks

Attempts were made to determine whether protein kinase $\mathrm{C}$ and $\mathrm{Gi} /$ Go proteins were involved in the S1P-evoked activation of Erks. The role of PI 3-kinase was also investigated as this kinase has been proposed as an early intermediate in the Gi $\beta \gamma$-mediated Erk signalling pathway (Hawes et al., 1996). As shown in Fig. 7A, long-term treatment of astrocytes with PMA $(1 \mu \mathrm{M}, 24 \mathrm{~h})$ (to downregulate protein kinase $\mathrm{C})$ inhibited $(-70 \pm 10 \%, n=4)$ the activation of Erk1 following incubation for 5 min with $10 \mu \mathrm{M}$ S1P. Preincubating the cells with the specific inhibitor of PI 3-kinase, LY294002 (20 $\mu \mathrm{M}$, $30 \mathrm{~min})$, partially inhibited $(-55 \pm 1 \%, n=4)$ the S1P-evoked activation of Erk1 (Fig. 7A). Combined pretreatments with PMA (24 h) and LY294002 (30 min) prevented the activation of Erk1 and reduced that of Erk2 (Fig. 7A). Pretreatment of astrocytes with PTX partially impaired $(-53 \pm 10 \%, n=4)$ Erk1 phosphorylation (Fig. 7B). Finally, combined pretreatments with PMA and PTX totally abolished the activation of Erk1 and markedly inhibited that of Erk2 (Fig. 7B). Altogether, these data indicate that Gi/Go proteins, PI 3-kinase and protein kinase $\mathrm{C}$ are essential components in the cascade of events leading to the activation of Erk1 by S1P. In agreement with a role of protein kinase $\mathrm{C}$, the acute application of PMA (1 $\mu \mathrm{M}, 5 \mathrm{~min})$ led to a marked stimulation of Erk1 and Erk2 (not shown).

\section{Roles of protein kinase C, PI 3-kinase and Gi/Go proteins in the S1P-evoked proliferation of astrocytes}

Because the S1P-evoked proliferation of astrocytes requires the activation of Erks, the roles of protein kinase C, PI 3-kinase and Gi/

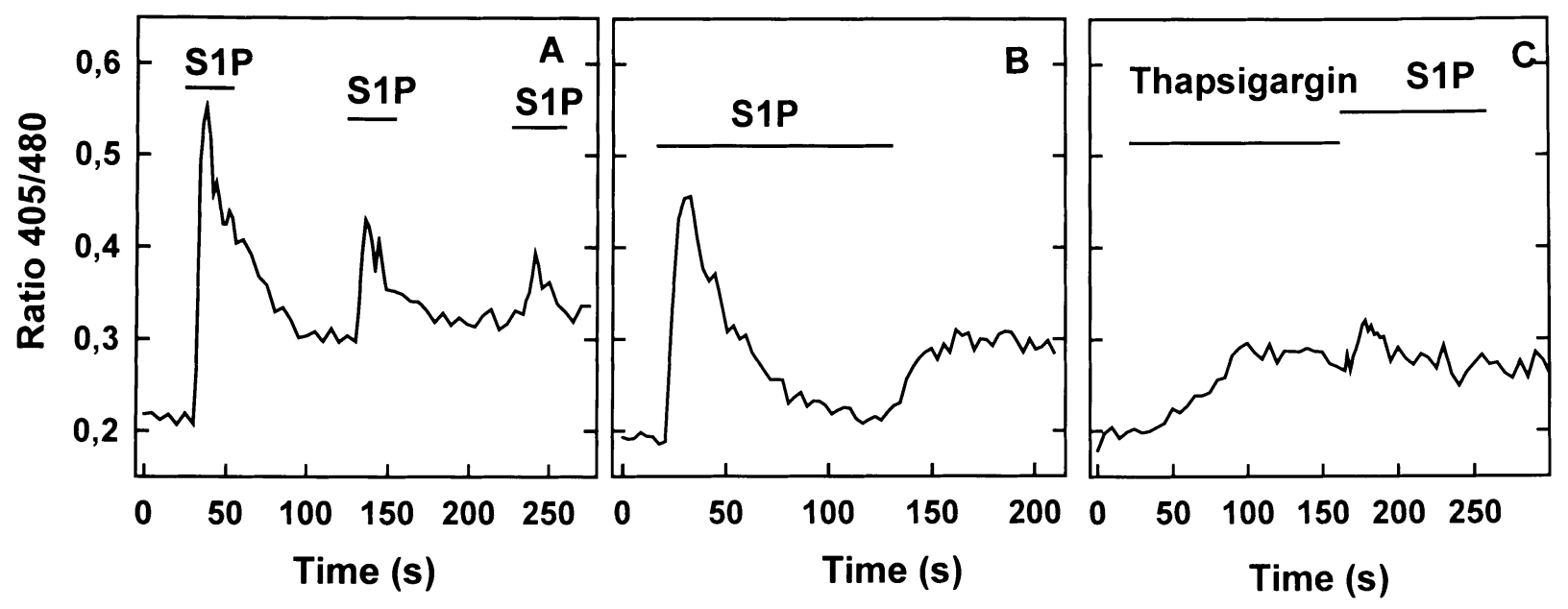

FIG. 5. S1P-induced increase in $\left[\mathrm{Ca}^{2+}\right]$ i. Cells were loaded for $45 \mathrm{~min}$ with Indo-1 AM and the variations of $\left[\mathrm{Ca}^{2+}\right] \mathrm{i}$ were measured by videofluoromicroscopy. The curve is the mean of responses observed in seven cells analysed simultaneously. (A) Cells received three successive applications of S1P $(10 \mu \mathrm{M})$ in a calcium-containing buffer, each application being followed by a 2-min washing with the same buffer. (B) Cells received an application of $\mathrm{S} 1 \mathrm{P}(10 \mu \mathrm{M})$ in a calcium-free buffer and were then exposed to a calcium-containing buffer. (C) Cells were first exposed for $2-3$ min to thapsigargin (10 $\mu \mathrm{M})$ in a calcium-containing buffer and then received an application of S1P $(10 \mu \mathrm{M})$ in the same buffer. Results are expressed as the fluorescence ratio measured at 405 and $480 \mathrm{~nm}$. Each experiment was performed at least three times. 
Go proteins in this response were also examined. Long-term treatment of astrocytes with PMA $(1 \mu \mathrm{M}, 24 \mathrm{~h})$ was totally ineffective on the stimulatory effect of S1P on astrocyte proliferation (Fig. 8). In contrast, pretreatment of the cells with either PTX or LY294002 totally prevented the proliferative effect of S1P (Fig. 8). PTX still inhibited cell proliferation in PMA-treated astrocytes (Fig. 8).
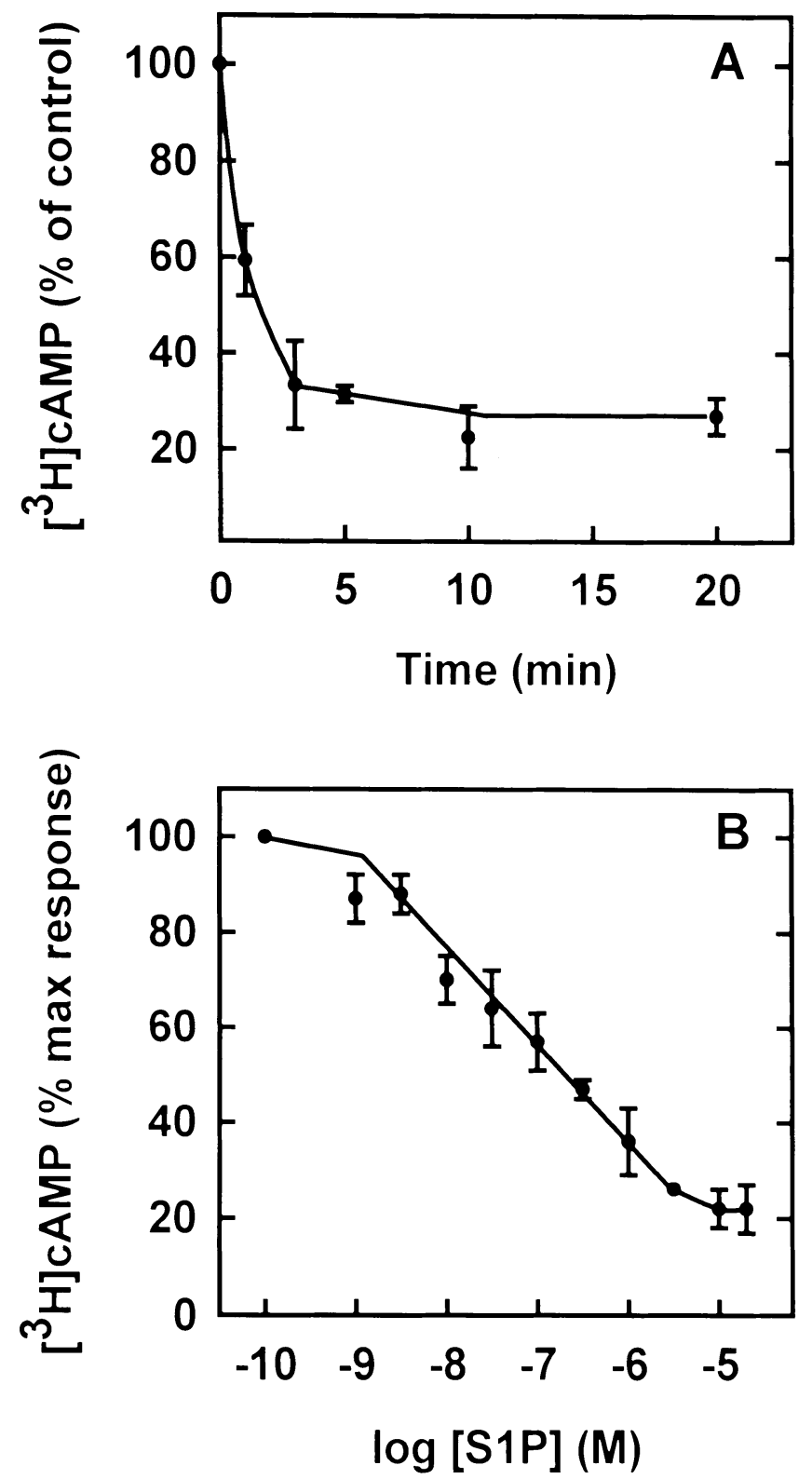

FIG. 6. S1P-induced inhibition of $\left[{ }^{3} \mathrm{H}\right] \mathrm{cAMP}$ production. (A) $\left[{ }^{3} \mathrm{H}\right]$ Adeninelabelled cells were incubated for various times with $10 \mu \mathrm{M}$ forskolin in the absence (control) or presence of $10 \mu \mathrm{M} \mathrm{S1P}$. Data, expressed as a percentage of $\left[{ }^{3} \mathrm{H}\right] \mathrm{cAMP}$ accumulation induced by forskolin in the absence of S1P (control), are the mean \pm SEM of results obtained in two independent experiments, each run in quadruplicate. (B) Cells were incubated for $5 \mathrm{~min}$ with $10 \mu \mathrm{M}$ forskolin in the presence of increasing concentrations of S1P. Data, expressed as a percentage of $\left[{ }^{3} \mathrm{H}\right] \mathrm{cAMP}$ accumulation induced by forskolin in the absence of S1P (maximal response) are the mean \pm SEM of results obtained in four independent experiments, each run in quadruplicate. In one typical experiment, the mean values of $\left[{ }^{3} \mathrm{H}\right] \mathrm{cAMP}$ measured were $628 \pm 26,9070 \pm 2021$ and $1448 \pm 142$ d.p.m. per well, for basal, forskolin and forskolin in the presence of $10 \mu \mathrm{M} \mathrm{S1P}$, respectively.
Altogether these data suggest that Gi/Go proteins and PI 3-kinase play a critical role in the stimulatory effect of S1P on astrocyte proliferation, whereas protein kinase $\mathrm{C}$ activity does not seem to be determinant.

\section{Discussion}

We have reported previously (Pébay et al., 1999) that striatal astrocytes are highly responsive to LPA, another platelet-derived lysophospholipid that acts on its own receptors (Hecht et al., 1996; An et al., 1998a; Bandoh et al., 1999). However, in contrast to that observed in several cell types, LPA does not exert a mitogenic effect on striatal astrocytes (Pébay et al., 1999). The present study indicates that striatal astrocytes are also targets for S1P. Indeed, they contain mRNAs for S1P receptors and their exposure to S1P triggers intracellular signalling cascades leading to the activation of Erks and cell proliferation.

Up to now, five types of S1P receptors have been identified. Edg-1, Edg-3, Edg-5 and Edg-8 receptors are probably expressed in several tissues, including the brain (An et al., 1998b; Glickman et al., 1999; Im et al., 2000), whereas Edg-6 seems to be specifically expressed in lymphoid tissues (Gräler et al., 1998). Thanks to RT-PCR experiments performed with specific primers for mouse gene, we have observed that primary striatal astrocytes contained mRNAs for both Edg-1 and Edg-3, but not Edg-5 receptors. Interestingly, this expression pattern appears to be different from that observed in mouse glioma cells because mRNAs for Edg-1 and Edg-5, but not for Edg-3 receptors, were found in these cells (Sato et al., 1999a). Although the sequence of the mouse Edg- 8 gene is not known, we have attempted to detect mRNA for this receptor in mouse astrocytes. Using primers designed from the rat cDNA sequence (Glickman et al., 1999) we did not observe cDNA amplification in these cells (not shown)

The mitogenic properties of S1P have been investigated in various cell systems. S1P appears to be either a full mitogen or a comitogen, ineffective alone, but acting in synergy with a growth factor (Zhang et al., 1991; Moolenaar, 1999; Rakhit et al., 1999). Antiproliferative properties of S1P have also been reported recently (Davaille et al., 2000). We show here that S1P alone is mitogenic in striatal astrocytes. In several cell types, Erk activation is a key step in the mitogenic process. This has been well-documented for growth factors stimulating receptor tyrosine kinases, but this is also the case for those acting on $\mathrm{G}$ protein-coupled receptors. It has been proposed (Brunet et al., 1999) that Erk must be activated in a prolonged manner in order to translocate into the nucleus and to induce proliferation. Our study indicates that S1P induces a sustained activation of Erk1 and Erk2 in striatal astrocytes, and that this activation is required for the proliferative effect of S1P. It is noteworthy that S1P also promotes the proliferation of endothelial cells which, like astrocytes, express Edg-1 and Edg-3, but not Edg-5, receptors (Kimura et al., 2000). This suggests that Edg-1 and/or Edg-3 receptors are responsible for the mitogenic effects of S1P in striatal astrocytes. It is important to mention here the recent study of Malek et al. (2001) which shows that, in contrast to other S1P receptors, the Edg-8 receptor is probably not involved in the mitogenic effects of S1P. Indeed, in cells transfected with Edg-8, the lysophospholipid inhibited, rather than stimulated, Erk activation and DNA synthesis.

To further elucidate the mechanisms underlying the stimulating effects of S1P on Erk activation and cell proliferation in striatal astrocytes, we have also analysed the early signalling events triggered by S1P. S1P markedly stimulated the production of inositol 

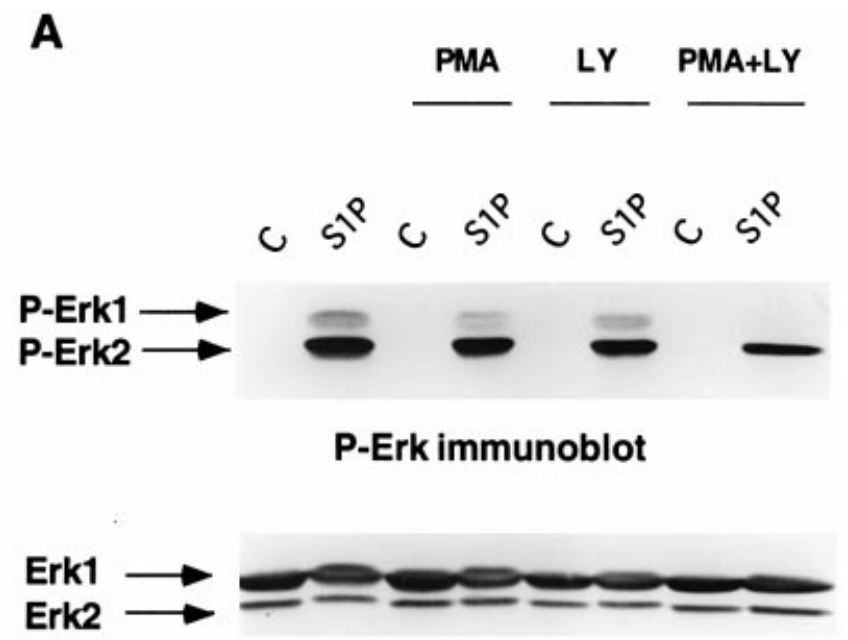

\section{Erk immunoblot}
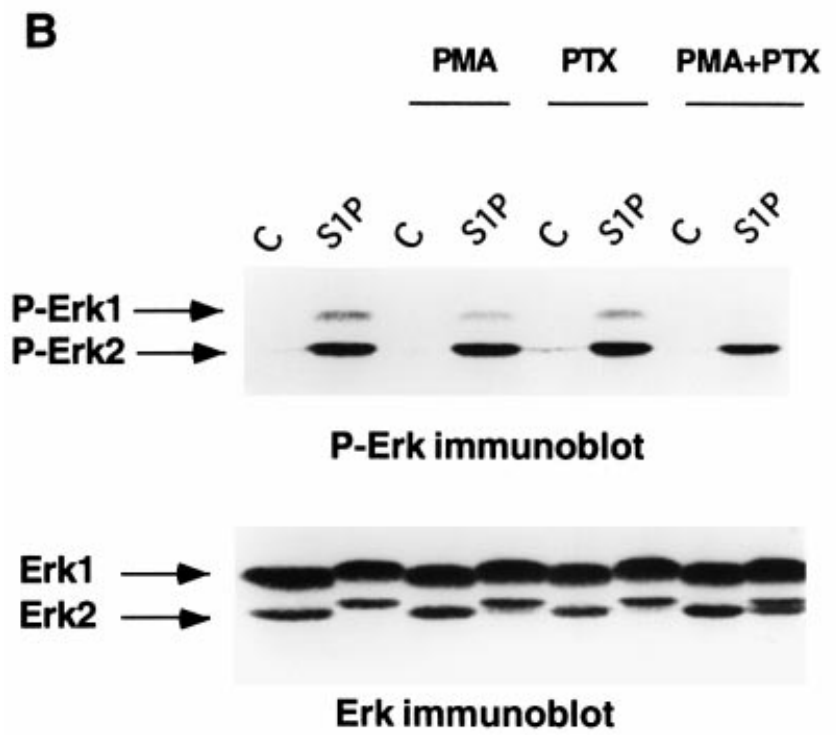

FIG. 7. Roles of protein kinase C, PI 3-kinase and Gi/Go proteins in the S1P-induced activation of Erks. (A) Cells were pretreated or not with either PMA (1 $\mu \mathrm{M}, 24 \mathrm{~h}), \mathrm{LY} 294002(20 \mu \mathrm{M}, 30 \mathrm{~min})$ or a combination of PMA and LY294002 and then incubated for $5 \mathrm{~min}$ in the absence (C, control) or presence of $10 \mu \mathrm{M} \mathrm{S1P}$. (B) Cells were pretreated or not with either PMA $(1 \mu \mathrm{M}, 24 \mathrm{~h})$, PTX $(1 \mu \mathrm{g} / \mathrm{mL}, 18 \mathrm{~h})$ or a combination of PTX and PMA and then incubated for $5 \mathrm{~min}$ in the absence (C) or presence of $10 \mu \mathrm{M} \mathrm{S1P}$. It can be noted that long-term treatment with PTX and/or PMA did not affect the amounts of Erk1 and Erk2 when compared with untreated cells. Data are representative of results from four independent experiments.

phosphates with an $\mathrm{EC}_{50}$ value similar to that found for its stimulatory effect on DNA synthesis. This response was inhibited following short-term treatment of the cells with a phorbol ester, which is in agreement with the protein kinase C-mediated feedback inhibition of phospholipase C. Both Edg-1 and Edg-3 receptors could

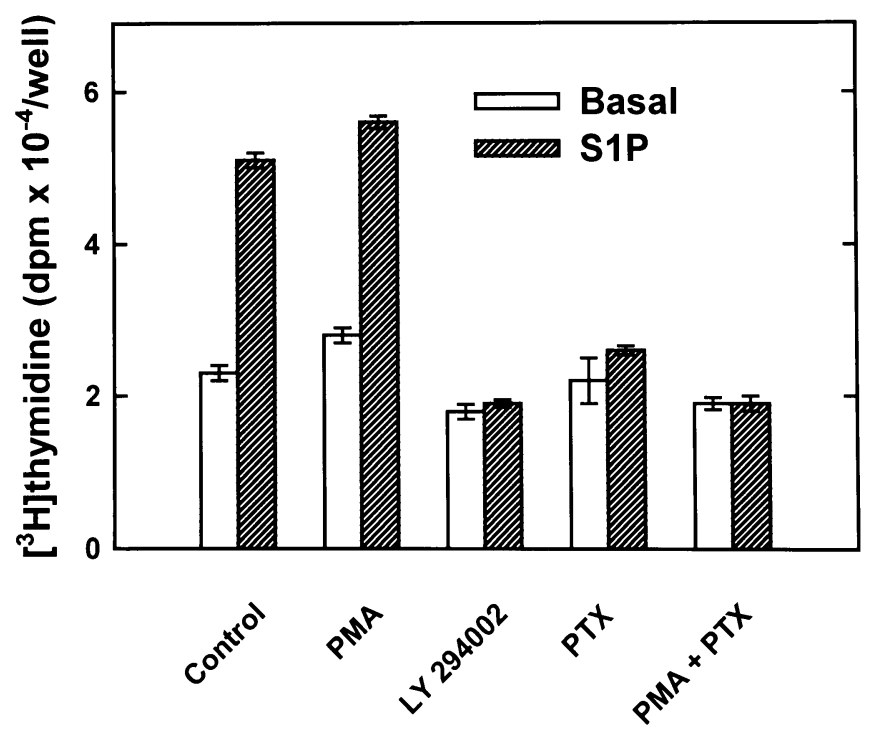

FIG. 8. Roles of protein kinase C, PI 3-kinase and Gi/Go proteins in the S1P-evoked DNA synthesis. Cells were pretreated or not (control) with

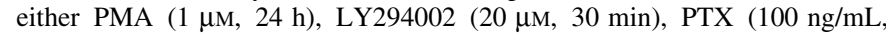
$18 \mathrm{~h})$ or a combination of PMA $(1 \mu \mathrm{M}, 24 \mathrm{~h})$ and PTX $(100 \mathrm{ng} / \mathrm{mL}, 18 \mathrm{~h})$, before being incubated for $24 \mathrm{~h}$ with $10 \mu \mathrm{M} \mathrm{S1P}$. Data are the mean \pm SEM of four determinations and are representative of results obtained in at least four independent experiments.

be involved as $\mathrm{S} 1 \mathrm{P}$ has been shown to stimulate such a response in hepatoma cells transfected with Edg-1 receptors, as well as in Chinese hamster ovary (CHO) cells transfected with either Edg-1 or Edg-3 receptors (An et al., 1999; Kon et al., 1999; Okamoto et al., 1999). However, the fact that this stimulatory effect of S1P was robust and occurred through a mechanism modestly sensitive to PTX is in accordance with the involvement of Edg-3 receptors in astrocytes (Okamoto et al., 1999).

S1P also markedly increased $\left[\mathrm{Ca}^{2+}\right] \mathrm{i}$ in striatal astrocytes. This response occurred with a similar short latency and rise time in all cells suggesting that S1P receptors are present in all recorded astrocytes. Probably, the transient increase in $\left[\mathrm{Ca}^{2+}\right]$ i resulted from a release of calcium from internal stores due to the stimulation of phosphoinositide hydrolysis by phospholipase C. Indeed, as for inositol phosphate formation, this S1P-induced increase in $\left[\mathrm{Ca}^{2+}\right] \mathrm{i}$ persisted in PTX-pretreated cells. Moreover, this calcium response was prevented by thapsigargin pretreatment and maintained in the absence of external calcium. Again, Edg-3 receptors could be responsible for this response as S1P-induced calcium mobilization has been observed in Edg-3- but not Edg-1-gene-transfected cells (Okamoto et al., 1998; Zondag et al., 1998; An et al., 1999; Kon et al., 1999). These observations of primary astrocytes are in accordance with those made of $\mathrm{C} 6$ glioma cells because in these cells, which also express Edg-3 receptors, the S1P-induced increase in $\left[\mathrm{Ca}^{2+}\right] \mathrm{i}$ is due to a calcium release from thapsigargin-sensitive stores (Tas \& Koschel, 1998) through a PTX-insensitive mechanism (Sato et al., 1999a).

In striatal astrocytes, S1P dramatically inhibited the production of cAMP evoked by either forskolin or isoproterenol, a $\beta$-adrenergic agonist. This S1P inhibitory response was impaired by PTX, suggesting the requirement of $\mathrm{Gi} / \mathrm{Go}$ proteins coupled to the receptors. The activation of Edg-1 receptors is probably involved in this S1P-evoked response because the overexpression of Edg-1 receptors in either Sf9 insect cells (Zondag et al., 1998) or CHO cells (Okamoto et al., 1998) has been shown to result in the inhibition by 
S1P of the forskolin-evoked accumulation of cAMP. These observations were confirmed by Kon et al. (1999) who also reported that this S1P inhibitory response did not occur in Edg-3- or Edg-5-genetransfected $\mathrm{CHO}$ cells.

S1P has been shown to activate Erk in non-nervous cells (Wu et al., 1995; Rakhit et al., 1999), in oligodendrocytes (Hida et al., 1999) and in C6 glioma cells (Sato et al., 1999a). In striatal astrocytes, S1P induced a strong activation of Erk1 and Erk2. Several mechanisms can be responsible for the activation of Erks by signals acting on $\mathrm{G}$ protein-coupled receptors. In particular, protein kinase $\mathrm{C}$, Gi/Go proteins (through their $\beta \gamma$ subunit) and PI 3-kinase could have regulatory roles (Malarkey et al., 1995; Gutkind, 1998; Derkinderen et al., 1999). According to our results, the stimulatory effect of S1P on Erk activation in striatal astrocytes is partially dependent on protein kinase C, PI 3-kinase and Gi/Go proteins. Impairment of the S1Pinduced activation of Erk1 and marked inhibition of Erk2 activation were observed when either both protein kinase $\mathrm{C}$ and PI 3-kinase or both $\mathrm{Gi} / \mathrm{Go}$ proteins and protein kinase $\mathrm{C}$ were inhibited. These data suggest that several separate mechanisms are involved in the full activation of Erks by S1P. We therefore propose that, in striatal astrocytes, the activation of Erks by S1P involves at least two signalling cascades. One pathway, which is Gi/Go-dependent, mediates the inhibition of adenylate cyclase, the release of the $\beta \gamma$ subunit, and probably the activation of PI 3-kinase. The other pathway mediates the activation of phospholipase $\mathrm{C}$ leading to protein kinase $\mathrm{C}$ activation (which is expected to activate the kinase Raf-1). Our hypothesis is in accordance with the presence of both Edg-1 and Edg-3 receptors on astrocytes. In fact, as suggested by results obtained on cells naturally expressing Edg-1 receptors, or on cells heterologously expressing Edg-1 or Edg-3 receptors, both Edg receptors could be involved in the activation of Erks (Lee et al., 1996; Okamoto et al., 1998; Zondag et al., 1998; Rakhit et al., 1999; Sato et al., 1999a; An et al., 2000). Interestingly, in airway smooth muscle cells, which express Edg-1 receptors, the stimulatory effect of S1P on Erk activity also involves PI 3-kinase (Rakhit et al., 1999). Finally, our results show that DNA synthesis could be impaired totally under conditions where Erks are still activated. This is in agreement with the pleiotropic biological properties of Erks and with the diversity of their substrates (Brunet et al., 1999; Derkinderen et al., 1999).

In conclusion, this study suggests the presence of at least two types of S1P receptors, Edg-1 and Edg-3, in striatal astrocytes. Probably, the activation of these receptors results in the inhibition of cAMP production and in the stimulation of phosphoinositide hydrolysis with the subsequent increase in $\left[\mathrm{Ca}^{2+}\right]$ i. These early transduction signals are most probably involved in the activation of Erks and the induction of astrocyte proliferation. S1P has been shown to be present in the brain, but at low concentration (Yatomi et al., 1997b; Edsall \& Spiegel, 1999; Murata et al., 2000), and evidence has not been reported for secretion by nerve cells. It is tempting to speculate that the effective concentrations of S1P observed in this study are those reached following traumatic injury of the central nervous system and disruption of the blood-brain barrier. Interestingly, S1P concentration in human serum is around 1-2 $\mu \mathrm{M}$ (Caligan et al., 2000; Murata et al., 2000). The mitogenic property of S1P on astrocytes could therefore have an important physiopathological role in the central nervous system considering the consequences of gliosis on neuron survival or death (Ridet et al., 1997).

\section{Acknowledgements}

This study was supported by INSERM (Institut National de la Santé et de la Recherche Médicale), CNRS (Centre National de la Recherche Scientifique) and Collège de France. The authors are grateful to B. Canton for providing RNA from 3T3 cells and to Drs M. Le Bert, H. Enslen and J.A. Girault for helpful discussions.

\section{Abbreviations}

$\left[\mathrm{Ca}^{2+}\right] \mathrm{i}$, intracellular calcium concentration; cAMP, cyclic AMP; BSA, bovine serum albumin; CHO, Chinese hamster ovary cells; DMEM, Dulbecco's modified Eagle's medium; $E d g$, endothelial differentiation gene; Edg, protein translated from the $E d g$ gene; EGTA, ethylene glycol-bis( $\beta$-aminoethyl ether)$N, N, N^{\prime}, N^{\prime}$-tetraacetic acid ethylene glycol; Erk, extracellular signal-regulated kinase; G protein, GTP-binding protein; HEPES, $N$-2[hydroxyethyl]piperazine- $N^{\prime}$-[2-ethanesulphonic acid]; Indo-1 AM, Indo-1 acetoxymethyl ester; LP, lysophospholipid; LPA, lysophosphatidic acid; MAP kinase, mitogen-activated protein kinase; MEM, minimum essential medium; PI 3-kinase, phosphatidylinositol 3-kinase; PMA, phorbol 12-myristate 13-acetate; PTX, pertussis toxin; RT-PCR, reverse transcriptase- polymerase chain reaction; S1P, sphingosine-1-phosphate; SDS, sodium dodecyl sulphate.

\section{References}

An, S., Bleu, T., Hallmark, O.G. \& Goetzl, E.J. (1998a) Characterization of a novel subtype of human $\mathrm{G}$ protein-coupled receptor for lysophosphatidic acid. J. Biol. Chem., 273, 7906-7910.

An, S., Bleu, T. \& Zheng, Y. (1999) Transduction of intracellular calcium signals through $\mathrm{G}$ protein mediated activation of phospholipase $\mathrm{C}$ by recombinant sphingosine-1-phosphate receptors. Mol. Pharmacol., 55, 787-794

An, S., Goetzl, E.J. \& Lee, H. (1998b) Signaling mechanisms and molecular characteristics of $\mathrm{G}$ protein-coupled receptors for lysophosphatidic acid and sphingosine-1-phosphate. J. Cell. Biochem. Suppl., 30/31, 147-157.

An, S., Zheng, Y. \& Bleu, T. (2000) Sphingosine-1-phosphate-induced cell proliferation, survival, and related signaling events mediated by $\mathrm{G}$ proteincoupled receptors Edg3 and Edg5. J. Biol. Chem., 275, 288-296.

Bandoh, K., Aoki, J., Hosono, H., Kobayashi, S., Kobayashi, T., MurakamiMurofushi, K., Tsujimoto, M., Arai, H. \& Inoue, K. (1999) Molecular cloning and characterization of a novel G-protein-coupled receptor, EDG-7, for lysophosphatidic acid. J. Biol. Chem., 274, 27776-27785.

Brunet, A., Roux, D., Lenormand, P., Dowd, S., Keyse, S. \& Pouysségur, J. (1999) Nuclear translocation of p42/p44 mitogen-activated protein kinase is required for growth factor-induced gene expression and cell cycle entry. EMBO J., 18, 664-674.

Caligan, T.B., Peters, K., Ou, J., Wang, E., Saba, J. \& Merill, A.H. (2000) A high-performance liquid chromatographic method to measure sphingosine1-phosphate and related compounds from sphingosine kinase assays and other biological samples. Anal. Biochem., 281, 36-44.

Chomszynski, P. \& Sacchi, N. (1987) Single-step method of isolation by acid guanidium thiocyanate-phenol-chloroform extraction. Anal. Biochem., 162, $156-159$.

Chun, J. (1999) Lysophospholipid receptors: implications for neural signaling. Crit. Rev. Neurobiol., 13, 151-168.

Davaille, J., Gallois, C., Habib, A., Li, L., Mallat, A., Tao, J., Levade, T. \& Lotersztajn, S. (2000) Antiproliferative properties of sphingosine-1phosphate in human hepatic myofibroblasts. J. Biol. Chem., 275, 34628-34633.

Delumeau, J.C., Tencé, M., Marin, P., Cordier, J., Glowinski, J. \& Prémont, J. (1991) Synergistic regulation of cytosolic $\mathrm{Ca}^{2+}$ concentration by adenosine and $\alpha 1$-adrenergic agonists in mouse striatal astrocytes. Eur. J. Neurosci., 3, 539-550.

Derkinderen, P., Eslen, H. \& Girault, J.A. (1999) The ERK/MAP-kinases cascade in the nervous system. Neuroreport, 10, 1-11.

Edsall, L.C., Pirianov, G.G. \& Spiegel, S. (1997) Involvement of sphingosine1-phosphate in nerve growth factor-mediated neuronal survival and differentiation. J. Neurosci., 17, 6952-6269.

Edsall, L.C. \& Spiegel, S. (1999) Enzymatic measurement of sphingosine-1phosphate. Anal. Biochem., 272, 80-86.

El-Etr, M., Cordier, J., Glowinski, J. \& Prémont, J. (1989) A neuro-glial cooperativity is required for the potentiation by 2-chloroadenosine of the muscarinic-sensitive phospholipase $\mathrm{C}$ in the striatum. J. Neurosci., 9, 1473-1480.

Glickman, M., Malek, R.L., Kwitek-Black, A.E., Jacob, H.J. \& Lee, N.H. (1999) Molecular cloning, tissue specific expression, and chromosomal 
localization of a novel nerve growth factor-regulated G-protein-coupled receptor, nrg-1. Mol. Cell. Neurosci., 14, 141-152.

Goetzl, E.J. \& An, S. (1998) Diversity of cellular receptors and functions for the lysophospholipid growth factors lysophosphatidic acid and sphingosine1-phosphate. FASEB J., 12, 1589-1598.

Gräler, M.H., Bernhardt, G. \& Lipp, M. (1998) EDG-6, a novel G-proteincoupled receptor related to receptors for bioactive lysophospholipids is specifically expressed in lymphoid tissue. Genomics, 53, 164-169.

Gutkind, J.S. (1998) The pathways connecting G protein-coupled receptors to the nucleus through divergent mitogen-activated protein kinase cascades. $J$. Biol. Chem., 273, 1839-1842.

Hawes, B.E., Luttrell, L.M., van Biesen, T. \& Lefkowitz, R.J. (1996) Phosphatidylinositol 3-kinase is an early intermediate in the G $\beta \gamma$-mediated mitogen-activated protein kinase signaling pathway. J. Biol. Chem., 271, 12133-12136.

Hecht, J.H., Weiner, J.A., Post, S.R. \& Chun, J. (1996) Ventricular zone gene1 (vzg-1) encodes a lysophosphatidic acid receptor expressed in neurogenic regions of the developing cerebral cortex. J. Cell. Biol., 135, 1071-1083.

Hida, H., Nagano, S., Takeda, M. \& Soliven, B. (1999) Regulation of mitogenactivated protein kinases by sphingolipid products in oligodendrocytes. $J$. Neurosci., 19, 7458-7467.

Im, D.-S., Heise, C.E., Ancelin, N., OíDowd, B.F., Shei, G.-J., Heaven, R.P., Rigby, M.R., Hla, T., Mandala, S., McAllister, G., George, S.R. \& Lynch, K.R. (2000) Characterization of a novel sphingosine-1-phosphate receptor, Edg-8. J. Biol. Chem., 275, 14281-14286.

Ishii, I. \& Chun, J. (1999) Lysophosphatidic acid/sphingosine-1-phosphateinduced cell aggregation/cluster formation of a neocortical neuroblast cell line. Soc. Neurosc. Abstr., 25, 1030.

Kimura, T., Watanabe, T., Sato, K., Kon, J., Tomura, H., Tamama, K.-I., Kuwabara, A., Kanda, T., Kabayashi, I., Ohta, H., Ui, M. \& Okajima, F. (2000) Sphingosine-1-phosphate stimulates proliferation and migration of human endothelial cells possibly through the lipid receptors, Edg-1 and Edg-3. Biochem. J., 348, 71-76.

Kon, J., Sato, K., Watanabe, T., Tomura, H., Kuwabara, A., Kimura, T., Tamama, K.I., Ishizuka, T., Murata, N., Kanda, T., Kobayashi, I., Ohta, H., Ui, M. \& Okajima, F. (1999) Comparison of intrinsic activities of the putative sphingosine-1-phosphate receptor subtypes to regulate several signaling pathways in their cDNA-transfected Chinese Hamster Ovary Cells. J. Biol. Chem., 74, 23940-23947.

Lee, M.J., Evans, M. \& Hla, T. (1996) The inducible G protein-coupled receptor edg-1 signals via the $\mathrm{Gi} /$ mitogen-activated protein kinase pathway. J. Biol. Chem., 271, 11272-11279.

Lee, M.-J., Van Brocklyn, J.R., Thangada, S., Liu, C.H., Hand, A.R., Menzeleev, R., Spiegel, S. \& Hla, T. (1998) Sphingosine-1-phosphate as a ligand for the G-protein-coupled receptor EDG-1. Science, 279, 1552-1555.

Liu, C.H. \& Hla, T. (1997) The mouse gene for the inducible G-proteincoupled receptor edg-1. Genomics, 43, 15-24.

Malarkey, K., Belham, C.M., Paul, A., Graham, A., McLees, A., Scott, P. \& Plevin, R. (1995) The regulation of tyrosine kinase signaling pathways by growth factor and G-protein-coupled receptors. Biochem. J., 309, 361-375.

Malek, R.L., Toman, R.E., Edsall, L.C., Wong, S., Chiu, J., Letterle, C.A., Van Brocklyn, J.R., Milstein, S., Spiegel, S. \& Lee, N.H. (2001) Nrg-1 belongs to the EDG family of G-protein coupled sphingosine-1-phosphate receptors. J. Biol. Chem., 276, 5692-5699.

Moolenaar, W. (1999) Bioactive lysophospholipids and their G proteincoupled receptors. Exp. Cell Res., 253, 230-238.

Moore, A.N., Kampfl, A.W., Zhao, X., Hayes, R.L. \& Dash, P.K. (1999) Sphingosine-1-phosphate induces apoptosis of cultured hippocampal neurons that requires protein phosphatases and activator protein-1 complexes. Neuroscience, 94, 405-415.

Murata, N., Sato, K., Kon, J., Tomura, H. \& Okajima, F. (2000) Quantitative measurement of sphingosine-1-phosphate by radioreceptor-binding assay. Anal. Biochem., 28, 115-120.

Okamoto, H., Takuwa, N., Gonda, K., Okazaki, H., Chang, K., Yatomi, Y., Shigematsu, H. \& Takuwa, Y. (1998) EDG1 is a functional sphingosine-1phosphate receptor that is linked via a Gi/Go to multiple signaling pathways, including phospholipase $\mathrm{C}$ activation, $\mathrm{Ca}^{2+}$ mobilization, Rasmitogen-activated protein kinase activation and adenylate cyclase inhibition. J. Biol. Chem., 273, 27104-27110.

Okamoto, H., Takuwa, N., Yatomi, Y., Gonda, K., Shigematsu, H. \& Takuwa, Y. (1999) EDG3 is a functional receptor specific for sphingosine-1- phosphate and sphingosylphosphorylcholine with signaling characteristics distinct from EDG1 and AGR16. Biochem. Biophys. Res. Com., 260, 203-208.

Pébay, A., Torrens, Y., Toutant, M., Cordier, J., Glowinski, J. \& Tencé, M. (1999) Pleiotropic effects of lysophosphatidic acid on striatal astrocytes. Glia, 28, 25-33.

Postma, F.R., Jalink, K., Hengeveld, T. \& Moolenaar, W.H. (1996) Sphingosine-1-phosphate rapidly induces Rho-dependent neurite retraction: action through a cell surface receptor. EMBO J., 15, 2388-2395.

Pyne, S. \& Pyne, N.J. (2000) Sphingosine-1-phosphate signalling in mammalian cells. Biochem. J., 349, 385-402.

Rakhit, S., Conway, A.-M., Tate, R., Bower, T., Pyne, N.J. \& Pyne, S. (1999) Sphingosine-1-phosphate stimulation of the p42/p44 mitogen-activated protein kinase pathway in airway smooth muscle. Biochem. J., 338, 643-649.

Ridet, J.L., Malhotra, S.K., Privat, A. \& Gage, F.H. (1997) Reactive astrocytes: Cellular and molecular cues to biological function. Trends Neurosci., 20, 570-577.

Sagan, S., Chassaing, G., Pradier, L. \& Lavielle, S. (1996) Tachykinin peptides affect differently the second messenger pathways after binding to CHO-expressed human NK1 receptors. J. Pharmacol. Exp. Ther., 27, 1-6.

Sato, K., Ishikawa, K., Ui, M. \& Okajima, F. (1999b) Sphingosine-1phosphate induces expression of early growth response- 1 and fibroblast growth factor-2 through mechanism involving extracellular signal-regulated kinase in astroglial cells. Mol. Brain Res., 74, 182-189.

Sato, K., Tomura, H., Igarashi, Y., Ui, M. \& Okajima, F. (1999a) Possible involvement of cell surface receptors in sphingosine-1-phosphate-induced activation of extracellular signal-regulated kinase in C6 glioma cells. Mol. Pharmacol., 55, 126-133.

Spiegel, S. \& Milstein, S. (2000) Functions of a new family of sphingosine-1phosphate receptors. Biochim. Biophys. Acta, 1484, 107-116.

Tas, P.W.L. \& Koschel, K. (1998) Sphingosine-1-phosphate induces a $\mathrm{Ca}^{2+}$ signal in primary rat astrocytes and a $\mathrm{Ca}^{2+}$ signal and shape changes in $\mathrm{C} 6$ rat glioma cells. J. Neurosci. Res., 52, 427-434.

Tencé, M., Pébay, A., Toutant, M., Prémont, J., Cordier, J. \& Glowinski, J. (1999) Pleiotropic effects of sphingosine-1-phosphate on astrocytes. Soc. Neurosci. Abstr., 25, 2205.

Van Brocklyn, J.R., Gräler, M.H., Bernhardt, G., Hobson, J.P., Lipp, M. \& Spiegel, S. (2000) Sphingosine-1-phosphate is a ligand for the G proteincoupled receptor EDG-6. Blood, 95, 2624-2629.

Van Brocklyn, J.R., Tu, Z., Edsall, L.C., Schmidt, R.R. \& Spiegel, S. (1999) Sphingosine-1-phosphate-induced rounding and neurite retraction are mediated by the G protein-coupled receptor H218. J. Biol. Chem., 274, 4626-4632.

Waeber, C. \& Chiu, M.L. (1999) In vitro autoradiographic visualization of guanosine- $5^{\prime}-0-\left(3-\left[{ }^{35} \mathrm{~S}\right]\right.$ thio $)$ triphosphate binding stimulated by sphingosine-1-phosphate and lysophosphatidic acid. J. Neurochem., 73, 1212-1221.

Wu, J., Spiegel, S. \& Sturgill, T.W. (1995) Sphingosine-1-phosphate rapidly activates the mitogen-activated protein kinase pathway by a $G$ proteindependent mechanism. J. Biol. Chem., 270, 11484-11488.

Yamazaki, Y., Kon, J., Sato, K., Tomura, H., Sato, M., Yoneya, T., Okazaki, H., Okajima, F. \& Ohta, H. (2000) Edg-6 as a putative sphingosine-1phosphate receptor coupling to $\mathrm{Ca}^{2+}$ signaling pathway. Biochem. Biophys. Res. Com., 268, 583-589.

Yatomi, Y., Igarashi, Y., Yang, L., Hisano, N., Qi, R., Asazuma, N., Satoh, K., Ozaki, Y. \& Kume, S. (1997a) Sphingosine-1-phosphate, a bioactive sphingolipid abundantly stored in platelets, is a normal constituent of human plasma and serum. J. Biochem., 121, 969-973.

Yatomi, Y., Welch, R.J. \& Igarashi, Y. (1997b) Distribution of sphingosine-1phosphate, a bioactive sphingolipid, in rat tissues. FEBS Lett., 404, 173-174.

Zhang, G., Contos, J.J.A., Weiner, J.A., Fukushima, N. \& Chun, J. (1999) Comparative analysis of three murine G-protein coupled receptors activated by sphingosine-1-phosphate. Gene, 227, 89-99.

Zhang, H., Desai, N.N., Olivera, A., Seki, T., Brooker, G. \& Spiegel, S. (1991) Sphingosine-1-phosphate, a novel lipid, involved in cellular proliferation. $J$. Cell. Biol., 114, 155-167.

Zondag, G.C.M., Postma, F.R., van Etten, I., Verlaan, I. \& Moolenaar, W.H. (1998) Sphingosine-1-phosphate signalling though the G protein-coupled receptor Edg-1. Biochem. J., 330, 605-609. 